\title{
What Influences Adoption of Green Award Criteria in a Public Contract? An Empirical Analysis of 2018 European Public Procurement Contract Award Notices
}

\author{
Chunling $\mathrm{Yu}^{1}$, Toru Morotomi ${ }^{1, *}$ and Haiping $\mathrm{Yu}^{2}$ \\ 1 Graduate School of Economics, Kyoto University, Yoshida-Honmachi, Sakyo-Ku, Kyoto 606-8501, Japan; \\ yu.chunling.62s@st.kyoto-u.ac.jp \\ 2 The International Institute for Industrial Environmental Economics, Lund University, Tegnérsplatsen 4, \\ 22100 Lund, Sweden; evelyn.hp.yu@gmail.com \\ * Correspondence: morotomi@econ.kyoto-u.ac.jp; Tel.: +81-757-533-510
}

Received: 9 January 2020; Accepted: 7 February 2020; Published: 10 February 2020

\begin{abstract}
Green public procurement (GPP) is a policy tool aiming to achieve environmental protection and resource reservation via public procurement. After decades of adaptation, what promotes and hinders its uptake in public contracting remains difficult to discern. This research explores factors that influence the adoption of green award criteria, covering features of procurement procedures, purchasers, tenderers, and the business sectors through empirical analysis of Probit regression combined with a fixed term method. The data is contract award notices (CAN) from 33 countries in Europe in 2018. Our findings suggest that framework agreements, the medical products sector, the health and social services sector, and the business services sector are negatively correlated with whether a contract is green. On the other hand, the contract value, Government Procurement Agreement (GPA)coverage, joint procurement, competitive dialogue, negotiation with competition (with a call for competition), restricted procedure, transport equipment sector, and food sector can positively correlate with green contracts, or these factors increase the possibility of a contract being green. Explicit explanations on these relations are provided. This research identifies factors relating with and influencing the application of green award criteria in public contracts, which would inform public sectors on efficient resources allocation in terms of increasing green public procurement performance.
\end{abstract}

Keywords: green public procurement; environmental economics and policy; European Union; Probit regression; fixed effects regression; GPA

\section{Introduction}

Government agencies around the world are increasingly advancing social and environmental policy goals by leveraging their own procurement dollars. Their influence on the market can be substantial, given the overall size and volume of purchasing that moves through government procurement offices. "The average share of public procurement in gross domestic product (GDP) in OECD countries is about $11 \%$, reaching $16 \%$ in the countries of the European Union" [1] (p. 41). Government expenditure on works, goods and services represents around 14\% of EU GDP, accounting for roughly EUR 1.8 trillion annually [2]. “The EU's Europe 2020 Strategy (Europe 2020) and Renewed Sustainable Development Strategy (Renewed SDS) identify green public procurement (GPP) as an essential market-based instrument for attaining the EU's economic and environmental objectives" [3] (p. 174).

Green public procurement (GPP) is a policy instrument designed to utilize this vast spending power to increase environmental protection and advance more environmentally sustainable economies. The European Commission defines GPP as: "a process whereby public authorities seek to procure 
goods, services and works with a reduced environmental impact throughout their life cycle when compared to goods, services and works with the same primary function that would otherwise be procured" [2] (p. 4). Sustainable Public Procurement (SPP) is a similar concept referring to "a process by which public authorities seek to achieve the appropriate balance between the three pillars of sustainable development-economic, social and environmental—when procuring goods, services or works at all stages of the project" [4]. SPP aims to improve environmental protection, energy saving, as well as labor security, small and medium-size enterprises support and a regional balance [5]. In light of this, GPP is subsumed within SPP with a focus on an environmental dimension.

In this research, green award criteria are used to identify green contracts. From a broad perspective, green criteria involve various environmental aspects and procurement procedures. In practice, GPP criteria can be environmentally related requirements set up by procurers during every step of the procurement process. GPP criterion is not only standard for identifying green products, but also for recognizing green suppliers and services. From the perspective of Life Cycle Costing, a GPP criterion not only involves the environmental impact of terminal products but also the impact of a raw material, production process, supply chain, and disposal phrases. We investigate the award criteria in the contract award notice and in the stage of awarding or choosing the winner of the bids using life cycle analysis.

The peer reviewed research on factors affecting the uptake of GPP from empirical economic standpoint is rather limited, although it is of apparent significance given the scale of carbon, water, and material footprints that government can cut through environmentally responsible procurement [6]. Lundberg, Marklund, Strömbäck, and Sundström [7] estimated how green criteria such as environmental management systems (EMS), eco labeling, and chemical restrictions affect a supplier's decision on whether to participate in procurement bids. They used the procurement data of the cleaning service sector from Sweden and got the result that GPP "was not effective as an environmental policy instrument" [7] (p. 506). However, EMS in their analysis was negatively affected by the participation possibility, which might indicate the costly implementation of the relevant systems. Testa, Iraldo, Frey, and Daddi [8] focused on public sectors' GPP adoption by interviewing 156 public authorities in Italy to answer the question of whether the awareness of a GPP toolkit and regulations, external assistance, the dimension of public authority, and ISO 14001 certification can influence the uptake of GPP practices. Their results showed that awareness and the dimension of public sectors positively and significantly affected the probability of adopting GPP practices.

Moreover, Nasiche and Ngugi [9] checked factors that determine the adoption of green procurement, especially involving the Kenya Pipeline Company, focusing on its green capacity, green incentives and pressure, cost of green products, and green supply capacity. Their analysis found that the internal green capacity, incentives and pressures mainly determined the adoption of GPP, based on semi-structured questionnaire results. Ahsan and Rahman [10] investigated challenges of GPP implementation in the Australian public healthcare sector. They found that the most critical challenges are insufficient legislation and financial support, lack of senior management support, and lack of government incentives. With structural equation modeling, Roman [11] investigated the conditions under which the organizations were more willing to prioritize sustainable procurement implementations, especially the leadership style of the leader surveying in US public agencies. Transformation leadership, innovativeness, and stakeholders' expectations were found to be critical.

GPP is a widely debated and highly expected policy used to address environmental problem. The potential of green public procurement as a strategic decarburization instrument has been acknowledged by major intergovernmental organizations including the EU, UN, and OECD. GPP considering carbon footprint of services and products in public tenders can help to reduce the emissions from government consumption [6]. Therefore, investigating what factors can relate with this policy is of significant value, while not being a sufficiently discussed topic. This research is a supplement to the existing literature. We examine public procurement features, i.e., procedures, volume, and award criteria of procurement per se, and the characteristics of purchasers, suppliers, and 
procurement objects from an empirical standpoint in a bid to find out the influential factors involved in green contracting. We employ a Probit and fixed effect regression model to analyze 2018 public contract awards available on Tenders Electronic Daily [12]—an official platform for publishing EU public contracts. In so doing, we aim to shed light on what and to what extent certain factors influence the application of green award criteria in public contracts. The results of this analysis can help to inform policy-makers wishing to increase the use GPP to allocate resources more effectively. The examined factors are different from those in the literature, and we cross-tested using logit regression, Probit regression without robustness check, and regress on subsamples of products, services, and works. The dataset employed in this paper encompasses 33 European nations and a wide variety of industry sectors.

This paper is organized as follows. The next section provides details on the regression model and limitations. Results of the analysis are then presented, followed by an interpretation of the results and general conclusions.

\section{Methodology and Data}

\subsection{Data and Variables}

In this research, whether a public contract is classified as green or not is based on its adoption of green criteria in the contract awarding stage. Green requirements can be applied throughout the whole process of public procurement, i.e., technical specifications (pass/fail entry thresholds), selection criteria, award criteria, and contract performance clauses. To date, the European Commission has developed 19 categories of GPP criteria, each corresponding to one specific group of procurement area, to facilitate member states in applying GPP on the ground [13]. One factor important to GPP concept is life cycle costing; due to this factor, green criteria does not merely focus on the greenness of terminal products, services, or works but extends to checking environmental performance in the whole life cycle of procured objects. It therefore can cover environmental impacts along a typical life cycle of products: raw materials, fabrication, assembly, packaging, transportation, maintenance, disposal. It can also cover the operational qualifications of contractors: management systems, staff capacity, and supply chain management, among other qualifications.

We investigated the influential factors of GPP, including the features of the procedures, the purchasers, the suppliers, and the business sectors. The data set we used is the 2018 contract award notice data in "Tenders Electronic Daily-public procurement notice" from EU Open Data Portal, "covering public procurement for the European Economic Area, Switzerland, and the former Yugoslav Republic of Macedonia". This data shows the most important information in contract award notices like "who bought what from whom, for how much, and which procedure and award criteria were used" [14]. We deleted the cancelled contracts and those launched by international organizations (European Union institution or others) from the dataset. The dataset may divide one procurement projects into several observations by using different contractors. We identify observations with IDs of contract award notices; this is one reason why we cannot consider the personal characteristics of individual tenderers. We also dropped 12 contracts out of over 230,000 contracts, whose values were more than or equal to $1 \mathrm{E}+11$ Euros, which at almost 10 percent of a country's GDP is not useful for our analysis.

The dependent variable "green contract" is a dummy variable for whether the contract is green. We assumed that the contract is green if it mentions at least one of several environmental words (see Table 1) in its award criteria. We collected these vocabularies from 19 EU GPP criteria documents [13]. In addition to the general vocabularies on the environment, like "environment", "sustainable", etc., there are also words on reduced emissions and toxicity, resource efficiency, ecolabels and criteria, and life cycle cost analysis. The dependent variable "green contract" equals one if the contract is green, and equals zero otherwise. 
Table 1. Environmental vocabularies for green contract identification.

\begin{tabular}{|c|c|}
\hline Aspects & Environmental Terms \\
\hline General words & $\begin{array}{l}\text { environment, environmental, sustainable sustainability, green, ecology, } \\
\text { ecological, wildlife }\end{array}$ \\
\hline $\begin{array}{l}\text { Reduced emission and } \\
\text { toxicity }\end{array}$ & $\begin{array}{l}\text { emission, pollution, waste, CO2, NOX, PM10, PM2.5, toxicity, hazardous, } \\
\text { seasonal produce, vegetable fats, vegetable oils, waste prevention, waste } \\
\text { sorting, organic, chemical restriction, noise emissions, biodegradable, } \\
\text { renewable, waste management, management of waste, double side printing, } \\
\text { air quality, air pollution, pollutant, GWP, hazard labeling, SVOC, titanium } \\
\text { dioxide, TiO, low-noise, carbon footprint, CF, soil management, wastewater, } \\
\text { COD, Sulfur emissions, GHG, greenhouse gas, organic gaseous carbon, OGC, } \\
\text { particulate matter, PM }\end{array}$ \\
\hline Resource efficiency & $\begin{array}{l}\text { energy, water efficiency, water consumption, gas consumption, fuel } \\
\text { consumption, resource efficiency, dimming, AECI, LED, water saving }\end{array}$ \\
\hline Labels and criteria & ISO 14001, EMS, EMAS, FSC, PEFC \\
\hline Life Cycle cost analysis & $\begin{array}{l}\text { recycle, recycling, recycled, recyclable, lifetime, whole life cost, lifecycle cost, } \\
\text { ecolabel, eco-label, warranty, warranties, longevity, repairable, repair, } \\
\text { reparability, repairability, rechargeable, endurance, replacement, end-of-life, } \\
\text { durability, dismantling, dismantle, disassembling, reuse, re-use, reused, } \\
\text { reusable, recovered fibers, maintenance, rehabilitation, LCA, waste recovery, } \\
\text { LCC, life cycle cost, lifespan, take back, take-back }\end{array}$ \\
\hline
\end{tabular}

Source: authors' elaboration. The dataset is in 28 official languages of EU and the vocabularies are translated into each language with Google Translator. GWP, the Global Warming Potential. SVOC, Semi-Volatile Organic Compounds. AECI, Annual Energy Consumption Indicator. EMAS, Eco-management and audit scheme. In ISO 14001, International Organization of Standardization (ISO) specifies the requirements for environmental management system helping one organization to improve its environmental performance. FSC, Forest Stewardship Council, http: //www.fsc.org/en/. PEFC, Program for the Endorsement of Forest Certification, http://www.pefc.org/internet/html.

Table 2 shows our independent variables, including open procedure (OPE), contract value, product, service, framework agreement, under Government Procurement Agreement (GPA), funded by EU, electrical auction, award method, central purchasing body (CPB), joint procurement, micro/small and medium-sized enterprises (SMEs), number of awarded SMEs, awarded to a group, number of offers, number of awards, as well as dummy variables for ten business sectors. We deem that these potential influential factors correlate with the possibility of a contract being green. Next, these factors are introduced in more detail.

The public procurement procedures covered in the dataset include open bids, competitive dialogues, negotiation with or without a call for competition, award without prior publication of a contract notice, and restricted procedure. The value used is value of a contract award notice, in EUR, without value-added tax. "If a value variable is missing, this variable looks for it in all other fields from which it could be taken" (refer to reference [14] for more details). Supplies, works, and services are three types of contract subjects in the database. From the coded data description of the dataset, "a work means the outcome of building or civil engineering works taken as a whole that is sufficient of itself to fulfil an economic or technical function" [15]. To avoid the dummy variable trap, we set only two dummy variables for two types of subject matters: products and services. These two variables have more contracts and larger total contract values than the others.

Directive 2014/24/EU defines a framework agreement as "an agreement between one or more contracting authorities and one or more economic operators, the purpose of which is to establish the terms governing contracts to be awarded during a given period, in particular with regard to price and, where appropriate, the quantity envisaged" [16] (p. 114). The World Trade Organization Government Procurement Agreement is a multilateral agreement aiming to create a level playing ground for suppliers from member states in bidding for government procurement. Members of GPA are subject to principles including but not limited to nondiscrimination, transparency, and rules for technical specification, selection, and evaluation of tenderers [17]. 
Contracting authorities compare the offers and base its final decision on award criteria. Directives of EU explain two different methods to award tenders: "the lowest price" and "the most economically advantageous tenders" (MEAT). That means the public sector can grant a contract to the tender with the lowest price, or to the tender that is most economically advantageous while comprehensively considering "quality, price, technical merit, aesthetic and functional characteristics, environmental characteristics, running costs, cost effectiveness, after sales service and technical assistance, delivery date and delivery period of completion", etc. [18] (p. 258). In Directive 2014/24/EU on public procurement, it is stated that the member states should have rights to prohibit or constraint cost or price-only procurement to encourage quality-orientated procurement [16].

Central purchasing bodies (CPB) and joint procurement are two ways to conduct cooperative purchasing for purchasers. A central purchasing body is defined as a contracting authority that acquires supplies or services, awards public contracts, or concludes framework agreements for supplies, services, and work, intended for one or more contracting authorities [19]. Joint procurement can be conducted in different forms: preparation of technical specifications for various projects, purchasers acting together, or purchasers entrusting one to carry out actions on behalf of all other participants [16].

This research employs the definition of micro, small and, medium-sized enterprises (SMEs) given by EU Commission Recommendation 2003/361 that encompass business entities with no more than 250 staff and an annual revenue less than 50 million EUR [20]. There are two variables for SMEs in our analysis. A variable of SMEs means whether a SME offer a bid for competition, and number of SMEs is the number of awarded SMEs.

On the aspect of business sectors, we identify six sectors that are top ten on the total quantity and on the total contract value at the same time. They are construction work, office supplies, construction service, business service, medical equipment, and health and social services. In addition, buildings, food and catering services, road transport vehicles, and energy-using products are four important procurement categories in GPP, according to "their environmental impacts, their budgetary importance, the potential to influence the market, as well as the availability of green alternatives" [2]. In light of this, transport equipment, transport service, food, and electrical products are also included in our analysis.

Table 2. Independent variables.

\begin{tabular}{|c|c|c|}
\hline Type & Variable Name & Value Assignment \\
\hline \multicolumn{3}{|r|}{ Contracts and procedures } \\
\hline Dummy & Award criteria & Type of award criteria is "the lowest price"; zero if MEAT \\
\hline Dummy & OPE & The procedure is open bids \\
\hline Numerical & Contract value & The log value (in Euro) awarded by the contract \\
\hline Dummy & Product & Equals one if the subject is supplies \\
\hline Dummy & Service & Equals one if the subject is services \\
\hline Dummy & $\begin{array}{l}\text { Framework } \\
\text { agreement }\end{array}$ & $\begin{array}{l}\text { "The notice involves the establishment of a framework agreement" } \\
\text { [15] (p. 13) }\end{array}$ \\
\hline Dummy & GPA & $\begin{array}{l}\text { "The contract is covered by the Government Procurement } \\
\text { Agreement" [15] (p.16) }\end{array}$ \\
\hline Dummy & Funded by EU & $\begin{array}{l}\text { "The contract is related to a project and/or program financed by } \\
\text { European Union funds" [15] (p. 18) }\end{array}$ \\
\hline Dummy & Electrical auction & "An electronic auction has been used" [15] (p. 19) \\
\hline \multicolumn{3}{|r|}{ Purchasers } \\
\hline Dummy & $\mathrm{CPB}$ & The contract is awarded by a central purchasing body \\
\hline Dummy & Joint procurement & Involves joint procurement among purchasers \\
\hline
\end{tabular}


Table 2. Cont.

\begin{tabular}{|c|c|c|}
\hline Type & Variable Name & Value Assignment \\
\hline \multicolumn{3}{|r|}{ Tenderers } \\
\hline Dummy & SMEs & The suppliers of a contract include at least one SMEs \\
\hline Numerical & Number of SMEs & The number of SMEs awarded by the purchaser \\
\hline Dummy & Awarded to a group & The contract has been awarded to a group of operators or suppliers \\
\hline Numerical & Number of offers & Number of tenders received \\
\hline Numerical & Number of awards & The number of contract awards for a given award notice \\
\hline \multicolumn{3}{|r|}{ Business sectors } \\
\hline Dummy & Construction work & Construction work \\
\hline Dummy & Medical equipment & "Medical equipment, pharmaceuticals and personal care products" \\
\hline Dummy & Construction service & "Architectural, construction, engineering and inspection services" \\
\hline Dummy & Health & "Health and social work services" \\
\hline Dummy & Office supplies & $\begin{array}{l}\text { "Office and computing machinery, equipment and supplies except } \\
\text { furniture and software packages" }\end{array}$ \\
\hline Dummy & Business service & $\begin{array}{l}\text { "Business services: law, marketing, consulting, recruitment, } \\
\text { printing and security" }\end{array}$ \\
\hline Dummy & Transport & "Transport equipment and auxiliary products to transportation" \\
\hline Dummy & Transport service & "Transport services (excl. Waste transport)" \\
\hline Dummy & Food & "Food, beverages, tobacco and related products" \\
\hline Dummy & Electrical product & $\begin{array}{l}\text { "Electrical machinery, apparatus, equipment and consumables; } \\
\text { lighting" }\end{array}$ \\
\hline
\end{tabular}

Source: authors' elaboration based on coding information of the database [15] and the TED website [21].

\subsection{Probit Regression}

We combine Probit regression with fixed effects regression in our analysis, country fixed term and month fixed term, as well as the robustness-controlled error term, to estimate whether the factors have effects on green contracts or green public procurement. The regression equation is shown below.

$$
Y_{i t}=\alpha+\beta C O N+\lambda P U R+v T E N+\gamma S E C+\delta_{i}+\delta_{t}+\varepsilon_{i t}
$$

$Y_{i t}$ is dummy for green contracts, $\mathrm{CON}$ is a vector of contract properties (OPE, value, subject matter, framework agreement, GPA, EU funds, and electrical auction, award method), PUR includes purchasers' characteristics: CPB and joint procurement. TEN is a bunch of tenderers' characteristics (dummy of SMEs in offering, number of awarded SMEs, awarded to a group, number of offers and awards). SEC contains dummies for ten important sectors of objectives of the contracts. $\delta_{i}$ is the country fixed term controlling omitted variables that vary in countries, but were constant within the year 2018. $\delta_{t}$ is the month fixed term representing unobservable variables changing over time, but not across countries. $\varepsilon_{i t}$ is error term, which is robust standard error.

In the Pobit regressions, the magnitude of the coefficients is not meaningful, so we need to calculate marginal effects to get the effect magnitude. We use average marginal effect in this analysis. The significance, signs of the coefficients and the marginal effects are checked. Furthermore, with the logit regression and Probit regression with normal standard error (rather than robust one), we cross check the verification of our results. We also regress on three subsamples on products, services and works to verify our analysis. 


\section{Results}

\subsection{Results of Descriptive Analysis}

\subsubsection{Green Contracts}

After collating the data, we get the total value of public procurement contracts in each country and calculate its percentage out of the corresponding GDP (Figures 1 and 2). The exchange rate of OECD is used, which is 0.8 euro per US dollar [22]. We can see that the public procurement takes various percentages in the European countries. France has the largest that is $21.24 \%$. In all, value of public procurement accounts for $7.1 \%$ of the total GDP of the countries. What is more, we get the proportion of green contract value, as well as the green contract quantity, out of all contracts in each country. If looking at all countries, the value of green contracts takes $21.81 \%$ of the total procurement value; and the green contract quantity accounts for $9.49 \%$ of all contracts. Switzerland, Denmark, Belgium, France, Ireland, Norway and the United Kingdom are countries with the highest uptake of GPP from our results. In 2012, Centre for European Policy Studies and College of Europe (core team) examined the GPP uptake in the EU27, and they got 38\% of the total value procured applied GPP criteria [23].

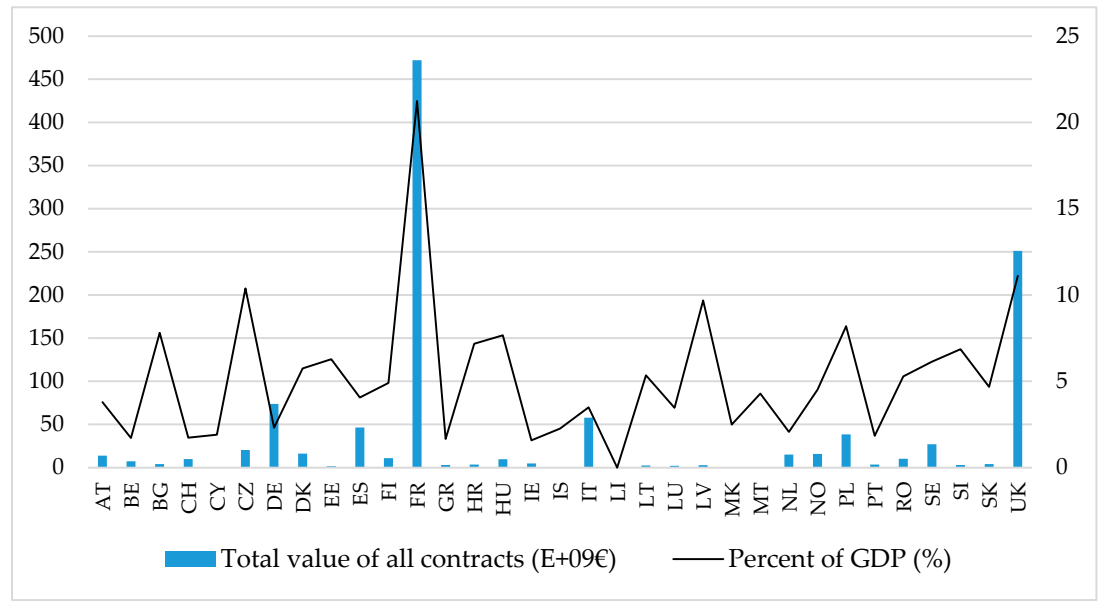

Figure 1. Public procurement of European countries.

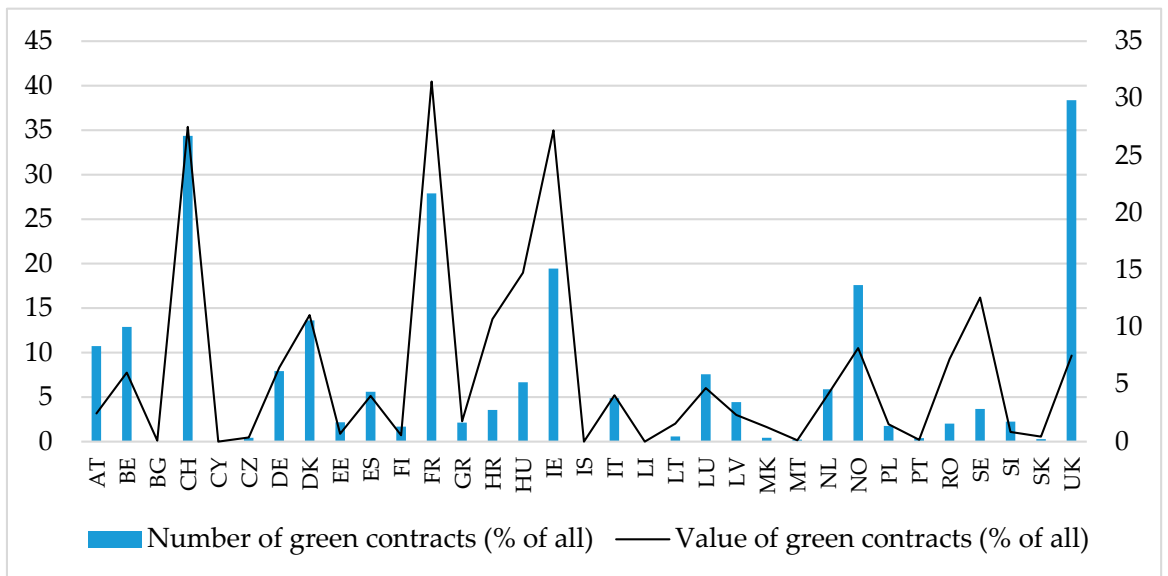

Figure 2. Green contracts in European countries. Source: authors' elaboration. AT: Austria; BE: Belgium; BG: Bulgaria; CH: Switzerland; CY: Cyprus; CZ: Czechia; DE: Germany; DK: Denmark; EE: Estonia; GR: Greece; ES: Spain; FI: Finland; FR: France; HR: Croatia; HU: Hungary; IE: Ireland; IS: Iceland; IT: Italy; LI: Liechtenstein; LT: Lithuania; LU: Luxembourg; LV: Latvia; MK: North Macedonia; MT: Malta; NL: Netherlands; No: Norway; PL: Poland; PT: Portugal; RO: Romania; SE: Sweden; SI: Slovenia; SK: Slovakia; UK: United Kingdom. 


\subsubsection{Business Sectors}

The data contains 45 categories of industry sectors (Table 3) for the contracts, which exceeds our analysis scope. To find the important ones, we investigate both the value and the quantity of contracts in each sector (see the table below). Six sectors are in the top ten for both value and quantity: (1) construction work, (2) office and computing machinery, equipment and supplies except furniture and software packages, (3) architectural, construction, engineering and inspection services, (4) medical equipment, pharmaceuticals and personal care products, (5) business service: law, marketing, consulting, recruitment, printing and security, (6) health and social work services. The construction work sector of ranks first for both value and quantity.

Table 3. Industry sectors in all contracts.

\begin{tabular}{|c|c|c|c|c|c|c|c|c|c|}
\hline Sector & 14 & 15 & 16 & 18 & 19 & 22 & 24 & 30 & 31 \\
\hline Value $(E+08 €)$ & 8.28 & 50.9 & 2.65 & 16.9 & 2.22 & 17.9 & 34.5 & 1110 & 422 \\
\hline Quantity & 532 & 4791 & 494 & 1568 & 315 & 1321 & 1367 & 7308 & 3602 \\
\hline Sector & 32 & 33 & 34 & 35 & 37 & 38 & 39 & 41 & 42 \\
\hline Value $(E+08 €)$ & 125 & 480 & 350 & 58.8 & 13.5 & 37.8 & 78.2 & 2.2 & 30.2 \\
\hline Quantity & 3087 & 23,501 & 11,287 & 1840 & 614 & 4988 & 4714 & 142 & 3741 \\
\hline Sector & 43 & 44 & 45 & 48 & 50 & 51 & 55 & 60 & 63 \\
\hline Value $(E+08 €)$ & 22.3 & 76.2 & 2120 & 94.3 & 265 & 8.08 & 79.2 & 366 & 132 \\
\hline Quantity & 771 & 4140 & 32,586 & 4691 & 9529 & 384 & 2396 & 6981 & 1313 \\
\hline Sector & 64 & 65 & 66 & 70 & 71 & 72 & 73 & 75 & 76 \\
\hline Value $(E+08 €)$ & 208 & 582 & 609 & 93.8 & 1320 & 218 & 18.9 & 43.6 & 9.79 \\
\hline Quantity & 2274 & 784 & 4999 & 461 & 19,086 & 7891 & 958 & 1153 & 179 \\
\hline Sector & 77 & 79 & 80 & 85 & 90 & 91 & 92 & 93 & 98 \\
\hline Value $(E+08 €)$ & 165 & 538 & 82.3 & 442 & 345 & 214 & 89.7 & 263 & 53.1 \\
\hline Quantity & 5135 & 12,778 & 3102 & 13,815 & 13,935 & 3261 & 1739 & 2865 & 1653 \\
\hline
\end{tabular}

Source: authors' elaboration. The bold numbers represent different sectors. The coding is set by EU and please refer to the Appendix A.

From Table 4, we can see that number of observations is 234,071 in total, but missing values occur in some variables. About $9 \%$ of the contracts are green under our selection standards, and $79 \%$ applied an open bids procedure (OPE). The proportion of product contracts and service contracts are $36 \%$ and $49 \%$, respectively; the remaining $15 \%$ is for work. Forty-four percent of contracts are under GPA and a very small number of contracts are funded by EU or are electrical. In our sample, central purchasing body awards only $5.6 \%$ of the contracts and $2.9 \%$ are joint procurement. On the aspect of tenderers, $42 \%$ contracts have SME tenderers providing an offer, and the average number of awarded SMEs in one contract is 2.57 . In addition, only $6 \%$ of the contracts are awarded to a group bidder, and the average number of offers and awards are 3.87 and 3, respectively. What is more, construction work, medical products, and construction services are the top three sectors for contract quantities, accounting for $14 \%, 10 \%$, and $8.2 \%$, respectively. 
Table 4. Descriptive analysis results.

\begin{tabular}{|c|c|c|c|c|c|}
\hline Variables & Observations & Mean & Standard Deviation & Max. & Min. \\
\hline Green contracts & 234071 & 0.09 & 0.29 & 0 & 1 \\
\hline \multicolumn{6}{|c|}{ Contracts and procedures } \\
\hline Award criteria & 123310 & 0.44 & 0.50 & 0 & 1 \\
\hline OPE & 234071 & 0.79 & 0.41 & 0 & 1 \\
\hline Log contract value & 206281 & 11.52 & 4.28 & -4.61 & 25.33 \\
\hline Product & 234071 & 0.36 & 0.48 & 0 & 1 \\
\hline Service & 234071 & 0.49 & 0.50 & 0 & 1 \\
\hline Framework agreement & 234071 & 0.15 & 0.35 & 0 & 1 \\
\hline GPA & 234071 & 0.54 & 0.50 & 0 & 1 \\
\hline Funded by EU & 234071 & 0.044 & 0.21 & 0 & 1 \\
\hline Electrical auction & 234071 & 0.020 & 0.14 & 0 & 1 \\
\hline \multicolumn{6}{|c|}{ Purchasers } \\
\hline $\mathrm{CPB}$ & 208991 & 0.056 & 0.23 & 0 & 1 \\
\hline Joint procurement & 234071 & 0.029 & 0.17 & 0 & 1 \\
\hline \multicolumn{6}{|c|}{ Tenderers } \\
\hline SMEs & 234071 & 0.42 & 0.49 & 0 & 1 \\
\hline Number of SMEs & 66925 & 2.57 & 9.46 & 0 & 998 \\
\hline Awarded to a group & 234071 & 0.061 & 0.24 & 0 & 1 \\
\hline Number of offers & 196702 & 3.87 & 8.57 & 0 & 998 \\
\hline Number of awards & 234071 & 3.00 & 9.97 & 0 & 742 \\
\hline \multicolumn{6}{|c|}{ Business sectors } \\
\hline Construction work & 234071 & 0.14 & 0.35 & 0 & 1 \\
\hline Medical products & 234071 & 0.10 & 0.30 & 0 & 1 \\
\hline Construction service & 234071 & 0.082 & 0.27 & 0 & 1 \\
\hline Health & 234071 & 0.059 & 0.24 & 0 & 1 \\
\hline Office supplies & 234071 & 0.031 & 0.17 & 0 & 1 \\
\hline Business service & 234071 & 0.055 & 0.23 & 0 & 1 \\
\hline Transport & 234071 & 0.048 & 0.21 & 0 & 1 \\
\hline Transport service & 234071 & 0.030 & 0.17 & 0 & 1 \\
\hline Food & 234071 & 0.020 & 0.14 & 0 & 1 \\
\hline Electrical product & 234071 & 0.015 & 0.12 & 0 & 1 \\
\hline
\end{tabular}

\subsection{Results of Regression Analysis}

\subsubsection{Results of Total Sample}

Table 5 shows the Probit regression results and marginal effects of the total sample. The first and second columns are without fixed effect controls. As a more precise analysis for causal relations, we added country and month fixed effects controls in the third and fourth columns, which are the main results. Based on Probit and fixed effect regression outcomes, OPE, a framework agreement, being funded by the EU, the medical equipment sector, sector of health and social services, and sector of 
business services are negatively related with whether a contract being green, with $5 \%$ or $1 \%$ significance levels. On the other hand, log of the contract value, GPA coverage, joint procurement, the construction service sector, the transport equipment sector, and the food sector can positively correlate with green contract, or these factors increase the possibility of a contract being green. With column (4), we can compare the magnitude of the effects. On the negative side, in descending order we find the health and social services sector, OPE, medical equipment sector, business services sector, framework agreements, and being funded by EU. On the positive side, our results in descending order are the food sector, the transport equipment sector, joint procurement, the construction services sector, log of the contract value, and GPA coverage.

In column (4), the coefficient of OPE means that the contracts applying open procedure possess a lower possibility of being green contracts by $5.6 \%$ compared with contracts with other procurement procedures, including competitive dialogue, negotiation, and restricted procedure, etc. The estimated results of a framework agreement, GPA, being funded by the EU, joint procurement, and the sector dummies can be explained in similar way. The contracts without framework agreements have a higher possibility of being green, by $3.1 \%$, than those within a framework. The contracts under GPA are more likely $(1.6 \%)$ to be green, while contracts funded by EU are less likely to be green $(2.2 \%)$. Joint contracts have a higher possibility of $4.3 \%$ to apply green award criteria. The coefficient of the contract value implies that a $1 \%$ growth in contract value will increase the probability of the contract being green by $0.48 \%$. Columns (5) and (6) can be used as creditability tests of the main Probit regression. We use a Logit regression in Column (5), which is a similar method for binary dependent variable analysis, and the estimated marginal effects are similar to those in Probit regression. In column (6), normal standard deviation is applied, rather than a robust one. Standard deviation in column (6) has trivial differences with those in column (3), which is an affirmation of our main Probit regression.

Table 5. Results of regressions. The dependent variable is "green contract".

\begin{tabular}{|c|c|c|c|c|c|c|}
\hline Regressors & $\begin{array}{c}\text { (1) } \\
\text { Probit-1 }\end{array}$ & $\begin{array}{c}(2) \\
\text { Marginal } \\
\text { Effect }\end{array}$ & $\begin{array}{c}(3) \\
\text { Probit-2 }\end{array}$ & $\begin{array}{c}\text { (4) } \\
\text { Marginal } \\
\text { Effect-Probit }\end{array}$ & $\begin{array}{c}\text { (5) } \\
\text { Marginal } \\
\text { Effect-Logit }\end{array}$ & $\begin{array}{c}\text { (6) } \\
\text { Probit-3 }\end{array}$ \\
\hline \multicolumn{7}{|c|}{ Contracts and procedures } \\
\hline OPE & $\begin{array}{c}-0.57 * * * \\
(0.031)\end{array}$ & $\begin{array}{l}-0.14^{* * *} \\
(0.0073)\end{array}$ & $\begin{array}{c}-0.26^{* * *} \\
(0.034)\end{array}$ & $\begin{array}{c}-0.056^{* * *} \\
(0.0073)\end{array}$ & $\begin{array}{c}-0.055^{* * *} \\
(0.0070)\end{array}$ & $\begin{array}{c}-0.26^{* * *} \\
(0.035)\end{array}$ \\
\hline $\begin{array}{l}\text { Contract } \\
\text { value }\end{array}$ & $\begin{array}{l}0.0085 * * \\
(0.0039)\end{array}$ & $\begin{array}{l}0.0021^{* *} \\
(0.00095)\end{array}$ & $\begin{array}{l}0.022 * * * \\
(0.0039)\end{array}$ & $\begin{array}{l}0.0048^{* * *} \\
(0.00084)\end{array}$ & $\begin{array}{l}0.0043^{* * *} \\
(0.00083)\end{array}$ & $\begin{array}{l}0.022^{* * *} \\
(0.0039)\end{array}$ \\
\hline Product & $\begin{array}{l}-0.075 \\
(0.094)\end{array}$ & $\begin{array}{l}-0.018 \\
(0.023)\end{array}$ & $\begin{array}{l}-0.029 \\
(0.092)\end{array}$ & $\begin{array}{c}-0.0063 \\
(0.020)\end{array}$ & $\begin{array}{c}-0.0058 \\
(0.019)\end{array}$ & $\begin{array}{l}-0.029 \\
(0.094)\end{array}$ \\
\hline Service & $\begin{array}{l}-0.022 \\
(0.091)\end{array}$ & $\begin{array}{c}-0.0054 \\
(0.022)\end{array}$ & $\begin{array}{l}-0.066 \\
(0.089)\end{array}$ & $\begin{array}{l}-0.014 \\
(0.019)\end{array}$ & $\begin{array}{l}-0.015 \\
(0.019)\end{array}$ & $\begin{array}{l}-0.066 \\
(0.091)\end{array}$ \\
\hline $\begin{array}{l}\text { Framework } \\
\text { agreement }\end{array}$ & $\begin{array}{l}0.15^{* * *} \\
(0.033)\end{array}$ & $\begin{array}{c}0.036^{* * *} \\
(0.008)\end{array}$ & $\begin{array}{c}-0.14^{* * *} \\
(0.035)\end{array}$ & $\begin{array}{c}-0.031^{* * *} \\
(0.0076)\end{array}$ & $\begin{array}{c}-0.031^{* * *} \\
(0.0074)\end{array}$ & $\begin{array}{c}-0.14^{* * *} \\
(0.035)\end{array}$ \\
\hline GPA & $\begin{array}{l}0.45^{* * *} \\
(0.025)\end{array}$ & $\begin{array}{l}0.11^{* * *} \\
(0.0061) \\
\end{array}$ & $\begin{array}{l}0.072 * * \\
(0.030)\end{array}$ & $\begin{array}{l}0.016^{* *} \\
(0.0065) \\
\end{array}$ & $\begin{array}{c}0.016^{* *} \\
(0.00066)\end{array}$ & $\begin{array}{l}0.072^{* *} \\
(0.030)\end{array}$ \\
\hline $\begin{array}{c}\text { Funded by } \\
\text { EU }\end{array}$ & $\begin{array}{c}-0.45^{* * *} \\
(0.039)\end{array}$ & $\begin{array}{l}-0.11^{* * *} \\
(0.0095)\end{array}$ & $\begin{array}{l}-0.10^{* *} \\
(0.044)\end{array}$ & $\begin{array}{l}-0.022 * * \\
(0.0095)\end{array}$ & $\begin{array}{c}-0.019 * \\
(0.010)\end{array}$ & $\begin{array}{l}-0.10^{* *} \\
(0.045)\end{array}$ \\
\hline $\begin{array}{l}\text { Electrical } \\
\text { auction }\end{array}$ & $\begin{array}{c}-0.32 * * \\
(0.13)\end{array}$ & $\begin{array}{c}-0.080 * * \\
(0.033)\end{array}$ & $\begin{array}{l}-0.14 \\
(0.14)\end{array}$ & $\begin{array}{l}-0.031 \\
(0.031)\end{array}$ & $\begin{array}{l}-0.033 \\
(0.032)\end{array}$ & $\begin{array}{l}-0.14 \\
(0.14)\end{array}$ \\
\hline $\begin{array}{l}\text { Award } \\
\text { criteria }\end{array}$ & Omitted & - & Omitted & - & Omitted & Omitted \\
\hline
\end{tabular}


Table 5. Cont.

\begin{tabular}{|c|c|c|c|c|c|c|}
\hline Regressors & $\begin{array}{c}\text { (1) } \\
\text { Probit-1 }\end{array}$ & $\begin{array}{c}(2) \\
\text { Marginal } \\
\text { Effect }\end{array}$ & $\begin{array}{c}(3) \\
\text { Probit-2 }\end{array}$ & $\begin{array}{c}(4) \\
\text { Marginal } \\
\text { Effect-Probit }\end{array}$ & $\begin{array}{c}\text { (5) } \\
\text { Marginal } \\
\text { Effect-Logit }\end{array}$ & $\begin{array}{c}(6) \\
\text { Probit-3 }\end{array}$ \\
\hline \multicolumn{7}{|c|}{ Purchasers } \\
\hline CPB & $\begin{array}{l}0.14^{* * *} \\
(0.048)\end{array}$ & $\begin{array}{c}0.035^{* * *} \\
(0.012)\end{array}$ & $\begin{array}{l}-0.018 \\
(0.050)\end{array}$ & $\begin{array}{c}-0.0039 \\
(0.011)\end{array}$ & $\begin{array}{c}-0.0041 \\
(0.011)\end{array}$ & $\begin{array}{l}-0.018 \\
(0.050)\end{array}$ \\
\hline $\begin{array}{c}\text { Joint } \\
\text { procurement }\end{array}$ & $\begin{array}{l}0.28^{* * *} \\
(0.061)\end{array}$ & $\begin{array}{l}0.070 * * * \\
(0.015)\end{array}$ & $\begin{array}{l}0.20^{* * *} \\
(0.063)\end{array}$ & $\begin{array}{c}0.043^{* * *} \\
(0.014)\end{array}$ & $\begin{array}{c}0.041^{* * *} \\
(0.013)\end{array}$ & $\begin{array}{l}0.20^{* * *} \\
(0.062)\end{array}$ \\
\hline \multicolumn{7}{|c|}{ Tenderers } \\
\hline SMEs & $\begin{array}{c}-0.064^{* *} \\
(0.029)\end{array}$ & $\begin{array}{c}-0.016 * * \\
(0.0071)\end{array}$ & $\begin{array}{c}0.00033 \\
(0.032)\end{array}$ & $\begin{array}{c}0.000071 \\
(0.0069)\end{array}$ & $\begin{array}{c}-0.000056 \\
(0.0069)\end{array}$ & $\begin{array}{c}0.00033 \\
(0.032)\end{array}$ \\
\hline $\begin{array}{l}\text { Number of } \\
\text { SMEs }\end{array}$ & $\begin{array}{c}-0.007 \\
(0.0049)\end{array}$ & $\begin{array}{l}-0.0017 \\
(0.0012)\end{array}$ & $\begin{array}{c}0.0013 \\
(0.0063)\end{array}$ & $\begin{array}{l}0.00027 \\
(0.0014)\end{array}$ & $\begin{array}{c}0.0004 \\
(0.0014)\end{array}$ & $\begin{array}{c}0.0013 \\
(0.0072)\end{array}$ \\
\hline $\begin{array}{l}\text { Awarded to } \\
\text { a group }\end{array}$ & $\begin{array}{c}-0.10 * * * \\
(0.037)\end{array}$ & $\begin{array}{c}-0.026^{* * *} \\
(0.0091)\end{array}$ & $\begin{array}{c}0.023 \\
(0.041) \\
\end{array}$ & $\begin{array}{c}0.0049 \\
(0.0088)\end{array}$ & $\begin{array}{c}0.0028 \\
(0.0091)\end{array}$ & $\begin{array}{c}0.023 \\
(0.040) \\
\end{array}$ \\
\hline $\begin{array}{l}\text { Number of } \\
\text { offers }\end{array}$ & $\begin{array}{c}0.0059 \\
(0.0049)\end{array}$ & $\begin{array}{c}0.0015 \\
(0.0012)\end{array}$ & $\begin{array}{l}-0.0092 \\
(0.0063)\end{array}$ & $\begin{array}{c}-0.002 \\
(0.0014)\end{array}$ & $\begin{array}{l}-0.0021 \\
(0.0014)\end{array}$ & $\begin{array}{l}-0.0092 \\
(0.0063)\end{array}$ \\
\hline $\begin{array}{l}\text { Number of } \\
\text { awards }\end{array}$ & $\begin{array}{l}-0.0030^{*} \\
(0.0018)\end{array}$ & $\begin{array}{l}-0.00073^{*} \\
(0.00044)\end{array}$ & $\begin{array}{c}-0.000047 \\
(0.0015)\end{array}$ & $\begin{array}{c}-0.000010 \\
(0.00033)\end{array}$ & $\begin{array}{c}0.00012 \\
(0.00036)\end{array}$ & $\begin{array}{c}-0.000047 \\
(0.0019)\end{array}$ \\
\hline \multicolumn{7}{|c|}{ Business sectors } \\
\hline $\begin{array}{l}\text { Construction } \\
\text { work }\end{array}$ & $\begin{array}{c}0.034 \\
(0.090)\end{array}$ & $\begin{array}{l}0.0083 \\
(0.022)\end{array}$ & $\begin{array}{c}0.031 \\
(0.088)\end{array}$ & $\begin{array}{l}0.0067 \\
(0.019) \\
\end{array}$ & $\begin{array}{l}0.0093 \\
(0.019) \\
\end{array}$ & $\begin{array}{c}0.031 \\
(0.090) \\
\end{array}$ \\
\hline $\begin{array}{c}\text { Medical } \\
\text { equipment }\end{array}$ & $\begin{array}{l}-0.46^{* * *} \\
(0.061)\end{array}$ & $\begin{array}{l}-0.11^{* * *} \\
(0.015)\end{array}$ & $\begin{array}{c}-0.26^{* * *} \\
(0.065)\end{array}$ & $\begin{array}{l}-0.055^{* * *} \\
(0.014)\end{array}$ & $\begin{array}{l}-0.052 * * * \\
(0.016)\end{array}$ & $\begin{array}{l}-0.26^{* * *} \\
(0.067)\end{array}$ \\
\hline $\begin{array}{c}\text { Construction } \\
\text { service }\end{array}$ & $\begin{array}{l}0.21 * * * \\
(0.038)\end{array}$ & $\begin{array}{l}0.052 * * * \\
(0.0093)\end{array}$ & $\begin{array}{l}0.11 * * \\
(0.042) \\
\end{array}$ & $\begin{array}{l}0.023 * * \\
(0.0091)\end{array}$ & $\begin{array}{l}0.029 * * * \\
(0.0090)\end{array}$ & $\begin{array}{l}0.11 * * \\
(0.045) \\
\end{array}$ \\
\hline Health & $\begin{array}{l}-0.037 \\
(0.085)\end{array}$ & $\begin{array}{c}-0.0091 \\
(0.021)\end{array}$ & $\begin{array}{c}-0.27 * * * \\
(0.086)\end{array}$ & $\begin{array}{c}-0.059 * * * \\
(0.019)\end{array}$ & $\begin{array}{c}-0.052 * * * \\
(0.019)\end{array}$ & $\begin{array}{c}-0.27^{* * *} \\
(0.086)\end{array}$ \\
\hline $\begin{array}{c}\text { Office } \\
\text { supplies }\end{array}$ & $\begin{array}{l}-0.17 * * \\
(0.074)\end{array}$ & $\begin{array}{l}-0.044 \text { ** } \\
(0.018)\end{array}$ & $\begin{array}{c}-0.11 \\
(0.079)\end{array}$ & $\begin{array}{l}-0.023 \\
(0.017)\end{array}$ & $\begin{array}{l}-0.018 \\
(0.018)\end{array}$ & $\begin{array}{c}-0.11 \\
(0.082)\end{array}$ \\
\hline $\begin{array}{l}\text { Business } \\
\text { service }\end{array}$ & $\begin{array}{c}-0.13^{* *} \\
(0.052)\end{array}$ & $\begin{array}{c}-0.032 * * \\
(0.013)\end{array}$ & $\begin{array}{c}-0.17 * * * \\
(0.054)\end{array}$ & $\begin{array}{c}-0.037^{* * *} \\
(0.012)\end{array}$ & $\begin{array}{c}-0.030 \text { ** } \\
(0.012)\end{array}$ & $\begin{array}{c}-0.17 * * * \\
(0.056)\end{array}$ \\
\hline $\begin{array}{l}\text { Transport } \\
\text { equipment } \\
\text { Transport } \\
\text { service }\end{array}$ & $\begin{array}{c}0.31 * * * \\
(0.056) \\
0.10 \\
(0.084)\end{array}$ & $\begin{array}{c}0.077^{* * *} \\
(0.014) \\
0.026 \\
(0.021)\end{array}$ & $\begin{array}{c}0.27 * * * \\
(0.060) \\
0.055 \\
(0.089)\end{array}$ & $\begin{array}{c}0.058^{* * *} \\
(0.013) \\
0.012 \\
(0.019)\end{array}$ & $\begin{array}{c}0.058^{* * *} \\
(0.013) \\
0.016 \\
(0.019)\end{array}$ & $\begin{array}{c}0.27^{* * *} \\
(0.059) \\
0.055 \\
(0.090)\end{array}$ \\
\hline Food & $\begin{array}{l}0.44^{* * *} \\
(0.068)\end{array}$ & $\begin{array}{l}0.11 * * * \\
(0.017)\end{array}$ & $\begin{array}{l}0.39 * * * \\
(0.080)\end{array}$ & $\begin{array}{c}0.084^{* * *} \\
(0.017)\end{array}$ & $\begin{array}{c}0.080^{* * *} \\
(0.017)\end{array}$ & $\begin{array}{l}0.39 * * * \\
(0.083)\end{array}$ \\
\hline $\begin{array}{l}\text { Electrical } \\
\text { product }\end{array}$ & $\begin{array}{c}-0.068 \\
(0.10)\end{array}$ & $\begin{array}{l}-0.017 \\
(0.025)\end{array}$ & $\begin{array}{c}-0.047 \\
(0.11)\end{array}$ & $\begin{array}{l}-0.010 \\
(0.024)\end{array}$ & $\begin{array}{l}-0.009 \\
(0.024)\end{array}$ & $\begin{array}{c}-0.047 \\
(0.11)\end{array}$ \\
\hline Constant & $\begin{array}{c}-0.67^{* * *} \\
(0.11)\end{array}$ & - & $\begin{array}{c}-0.77^{* * *} \\
(0.15)\end{array}$ & - & - & $\begin{array}{c}-0.77^{* * *} \\
(0.15)\end{array}$ \\
\hline $\begin{array}{l}\text { Country } \\
\text { fixed term }\end{array}$ & No & No & Yes & Yes & Yes & Yes \\
\hline $\begin{array}{l}\text { Month fixed } \\
\text { term }\end{array}$ & No & No & Yes & Yes & Yes & Yes \\
\hline Std. Err & Yes & Yes & Yes & Yes & Yes & No \\
\hline Observations & 16,113 & 16,113 & 16,111 & 16,111 & 16,111 & 16,111 \\
\hline Pseudo R2 & 0.0995 & - & 0.2095 & - & - & 0.2095 \\
\hline
\end{tabular}




\subsubsection{Results of Subsamples on Subject Matters}

It is widely accepted that different types of procurement subject matters possess different features. When looking into each branch of product, service, and work, the influential factors may be diverse. In Table 6, we separate our sample into three subgroups according to the subject matters of the contracts, and only show the significant coefficients.

For product contracts, a framework agreement, the number of SMEs, and being related to the medical products sector reduce the possibility of a contract being green. In contrast, the contract value, GPA, joint procurement, business service sector, transport equipment sector, and food sector increase this possibility. In service procurements, OPE, a framework agreement, the number of offers, being funded by the EU, the health sector, business service sector, and construction work sector are significantly and negatively related with a green contract. The two factors that are positively related are the contract value and number of SMEs. The sample size of work contracts is the smallest one, and we obtain significant negative significant coefficients for a framework agreement and the number of SMEs. In contrast, we obtain positive ones for contract value and the number of awards.

Table 6. Regression results with subsamples of subject matters. The dependent variable is "green contract".

\begin{tabular}{|c|c|c|c|c|c|c|}
\hline Regressors & $\begin{array}{c}\text { (1) } \\
\text { Product }\end{array}$ & $\begin{array}{c}(2) \\
\text { Marginal } \\
\text { Effect }\end{array}$ & $\begin{array}{c}(3) \\
\text { Service }\end{array}$ & $\begin{array}{c}(4) \\
\text { Marginal } \\
\text { Effect }\end{array}$ & $\begin{array}{c}(5) \\
\text { Work }\end{array}$ & $\begin{array}{c}\text { (6) } \\
\text { Marginal } \\
\text { Effect }\end{array}$ \\
\hline \multicolumn{7}{|c|}{ Contracts and procedures } \\
\hline OPE & & & $\begin{array}{c}-0.33^{* * *} \\
(0.043)\end{array}$ & $\begin{array}{c}-0.076^{* * *} \\
(0.010)\end{array}$ & & \\
\hline Contract value & $\begin{array}{c}0.014 * \\
(0.0072)\end{array}$ & $\begin{array}{c}0.0025^{*} \\
(0.0013)\end{array}$ & $\begin{array}{l}0.022 * * * \\
(0.0049)\end{array}$ & $\begin{array}{c}0.0052 * * * \\
(0.0012)\end{array}$ & $\begin{array}{l}0.035^{*} \\
(0.021)\end{array}$ & $\begin{array}{c}0.0079^{*} \\
(0.0048)\end{array}$ \\
\hline $\begin{array}{c}\text { Framework } \\
\text { agreement }\end{array}$ & $\begin{array}{l}-0.13^{* *} \\
(0.060)\end{array}$ & $\begin{array}{c}-0.025^{* *} \\
(0.011)\end{array}$ & $\begin{array}{c}-0.099 * * \\
(0.048)\end{array}$ & $\begin{array}{c}-0.023^{* *} \\
(0.011)\end{array}$ & $\begin{array}{c}-0.26 \text { * } \\
(0.15)\end{array}$ & $\begin{array}{c}-0.059 * \\
(0.034)\end{array}$ \\
\hline GPA & $\begin{array}{l}0.18^{* * *} \\
(0.057)\end{array}$ & $\begin{array}{c}0.032 * * * \\
(0.010)\end{array}$ & & & & \\
\hline Funded by EU & & & $\begin{array}{c}-0.23^{* * *} \\
(0.064)\end{array}$ & $\begin{array}{c}-0.054^{* * *} \\
(0.015)\end{array}$ & & \\
\hline \multicolumn{7}{|l|}{ Electrical auction } \\
\hline \multicolumn{7}{|l|}{ Award criteria } \\
\hline \multicolumn{7}{|c|}{ Purchasers } \\
\hline \multicolumn{7}{|l|}{$\mathrm{CPB}$} \\
\hline Joint procurement & $\begin{array}{l}0.22 * * \\
(0.10)\end{array}$ & $\begin{array}{l}0.040^{* *} \\
(0.019)\end{array}$ & & & & \\
\hline \multicolumn{7}{|c|}{ Tenderers } \\
\hline \multicolumn{7}{|l|}{ SMEs } \\
\hline Number of SMEs & $\begin{array}{c}-0.020 * * \\
(0.0088)\end{array}$ & $\begin{array}{c}-0.0036^{* *} \\
(0.0016)\end{array}$ & $\begin{array}{c}0.029^{* * *} \\
(0.01)\end{array}$ & $\begin{array}{c}0.0068^{* * *} \\
(0.0023)\end{array}$ & $\begin{array}{c}-0.060 \text { ** } \\
(0.026)\end{array}$ & $\begin{array}{c}-0.014^{* *} \\
(0.0059)\end{array}$ \\
\hline \multicolumn{7}{|l|}{ Awarded to a group } \\
\hline Number of offers & & & $\begin{array}{c}-0.032^{* * *} \\
(0.0091)\end{array}$ & $\begin{array}{c}-0.0076^{* * *} \\
(0.0021)\end{array}$ & & \\
\hline Number of awards & & & & & $\begin{array}{l}0.030^{* * *} \\
(0.0099)\end{array}$ & $\begin{array}{c}0.0068^{* * *} \\
(0.0022)\end{array}$ \\
\hline
\end{tabular}


Table 6. Cont.

\begin{tabular}{|c|c|c|c|c|c|c|}
\hline Regressors & $\begin{array}{c}\text { (1) } \\
\text { Product }\end{array}$ & $\begin{array}{c}(2) \\
\text { Marginal } \\
\text { Effect }\end{array}$ & $\begin{array}{c}(3) \\
\text { Service }\end{array}$ & $\begin{array}{c}(4) \\
\text { Marginal } \\
\text { Effect }\end{array}$ & $\begin{array}{c}(5) \\
\text { Work }\end{array}$ & $\begin{array}{c}\text { (6) } \\
\text { Marginal } \\
\text { Effect }\end{array}$ \\
\hline \multicolumn{7}{|c|}{ Business sectors } \\
\hline Construction work & & & $\begin{array}{c}-0.27 * \\
(0.16)\end{array}$ & $\begin{array}{c}-0.064 \text { * } \\
(0.036)\end{array}$ & & \\
\hline Medical equipment & $\begin{array}{c}-0.19 * * \\
(0.074)\end{array}$ & $\begin{array}{c}-0.034^{* *} \\
(0.014)\end{array}$ & & & & \\
\hline \multicolumn{7}{|l|}{ Construction service } \\
\hline Health & & & $\begin{array}{c}-0.30 * * * \\
(0.088)\end{array}$ & $\begin{array}{c}-0.071^{* * *} \\
(0.021)\end{array}$ & & \\
\hline \multicolumn{7}{|l|}{ Office supplies } \\
\hline Business service & $\begin{array}{l}0.52 * \\
(0.29)\end{array}$ & $\begin{array}{l}0.096^{*} \\
(0.052)\end{array}$ & $\begin{array}{c}-0.19^{* * *} \\
(0.057)\end{array}$ & $\begin{array}{c}-0.044^{* * *} \\
(0.013)\end{array}$ & & \\
\hline Transport equipment & $\begin{array}{l}0.38^{* * *} \\
(0.069)\end{array}$ & $\begin{array}{c}0.070 * * * \\
(0.013)\end{array}$ & & & & \\
\hline \multicolumn{7}{|l|}{ Transport service } \\
\hline Food & $\begin{array}{l}0.23^{* *} \\
(0.091)\end{array}$ & $\begin{array}{l}0.043^{* *} \\
(0.017)\end{array}$ & & & & \\
\hline
\end{tabular}

\begin{tabular}{ccccccc}
\hline \multicolumn{1}{l}{ Electrical product } & \multicolumn{1}{c}{} & & & & \\
\hline Constant & & & & & & \\
\hline Country fixed term & Yes & Yes & Yes & Yes & Yes & Yes \\
\hline Month fixed term & Yes & Yes & Yes & Yes & Yes & Yes \\
\hline Observations & 6111 & 6111 & 8408 & 8408 & 1230 & 1230 \\
\hline Pseudo R2 & 0.2328 & - & 0.2120 & - & 0.2611 & - \\
\hline
\end{tabular}

Source: authors' elaboration with Stata. Robust standard deviation are shown in the parentheses. ${ }^{*} p<0.1,{ }^{* *} p<$ $0.05, * * * p<0.01$. All regressors are included in each regression, and only significant results are shown.

Compared with the results of integrated regression in Table 5, the coefficients of contract value in three subsamples are also positive, within a $10 \%$ significance level. That increases the credibility of the positive relation between the contract value and green features of a contract. However, the coefficient in a service group is more significant (within 1\%). Analysis for framework agreements is similar; the results in the total sample and the three subsamples are all negative, and those for the product group and service group are more significant (within $5 \%$ ).

For some factors, the estimated effects we got in the integrated regression are supported only by one subgroup's analysis. For example, the OPE procedure negatively affected the probability of a green contract in the total sample. The only result in the service subsample is in line with it, while there are no significant results in product and work procurement. For variables of GPA, joint procurement, the medical equipment sector, transport equipment sector, and food sector, the signs of their coefficients in the product group are the same with those in the total sample, but we find no significant results in service and work subsamples. On the other hand, for factors of OPE, funded by EU, the health sector, and the business service sector, their estimated effects' signs only in the service group are consistent with those in the total sample. That means it is tested that different types of subject matters have various influential factors, and one factor may display effects to a different extent in different subsamples.

There are three variables for which there are no significant results in the total sample, but significant ones in subsamples. The number of SMEs is one such variable, whose coefficients in product, service, and work subsamples are all statistically significant. The number of SMEs awarded in one contract decreases the possibility of the contract being green for products and works, while increasing the 
possibility for services. What is more, the number of offers negatively correlates with the green contracts only for services, and the number of awards positively correlates with the green contracts only for works.

\section{Discussion}

\subsection{Proper Procedures for GPP}

An open procedure was tested to change oppositely with the possibility of a contract being green. Conversely, a green contract is more likely to apply other procedures, than open procedure. To estimate the correlation more precisely, we include a competitive dialogue, negotiation, and restricted procedure procedures into our regression. From Table 7, open procedure is no longer significant, as well as the negotiation without a call for competition. Competitive dialogue, negotiation with a call for competition, and restricted procedures all positively correlate with green contracts, having higher possibility than other procedures by $19 \%, 12 \%$, and $10 \%$, respectively. Other variables in the regression stay the same and statistical significance, signs and magnitudes of their coefficients barely change, compared with our main results (column (4) in Table 5).

Table 7. Regression results on procedures. Dependent variable is "green contract".

\begin{tabular}{ccc}
\hline Procedures & Probit & Marginal Effect \\
\hline Open procedure (OPE) & 0.21 & 0.046 \\
Competitive dialogue (COD) & $(0.15)$ & $(0.032)$ \\
\hline Negotiation without a call for competition (NOC/NOP) & $0.88^{* * *}$ & $0.19^{* * *}$ \\
& $(0.23)$ & $(0.05)$ \\
\hline Negotiation with a call for competition (NIC/NIP) & -0.024 & -0.0052 \\
& $(0.19)$ & $(0.041)$ \\
\hline \multirow{2}{*}{ Restricted procedure } & $0.56^{* * *}$ & $0.12^{* * *}$ \\
& $(0.15)$ & $(0.033)$ \\
\hline Other variables in Equation (1) & $0.48^{* * *}$ & $0.10^{* * *}$ \\
Country fixed term & $(0.16)$ & $(0.034)$ \\
\hline Month fixed term & Yes & Yes \\
\hline Observations & Yes & Yes \\
\hline Pseudo R2 & Yes & Yes \\
\hline
\end{tabular}

Source: authors' elaboration with Stata. Robust standard deviation is shown in the parentheses. ${ }^{*} p<0.1,{ }^{* *} p<0.05$, *** $p<0.01$.

The results show that the most popular procedures used in green procurement is competitive dialogue followed with negotiation with a call for competition and restricted procedures. Competitive dialogue usually consists of a dialogue phase and a bidding phase, and in the former stage, public authorities can discuss the contracts with bidders. The input from economic operators can help the purchasing authorities to identify and organize proper requirements [24]. Ard den Outer, public procurement consultant of Rotterdam Municipality, said: "one important thing is that you have to have proper knowledge of what the market is able to deliver, which step the market is able to make", in an interview with us in November 2019. The two-stage procedures-restricted procedures, competitive procedures with negotiation, and competitive dialogues [16] all increase information collection.

Competitive dialogue can often occur in complex projects [25]. It is encouraged in the new directives for public procurement of EU that "for services or supplies that require adaptation or design efforts, the use of a competitive procedure with negotiation or competitive dialogue is likely to be of value" [16]. GPP involves the selection and weights of environmental criteria in technical 
specification, award criteria and contract clauses, which makes it complicated. It is reasonable to think that competitive dialogue and negotiation with a call for competition are trends in GPP projects, to guarantee the information symmetry between the environmental needs of governments and available access to the best solution in the market.

\subsection{Contract Value and Joint Procurement}

Contract value and joint procurement both positively correlate with the likelihood of a contract being green. Joint procurement integrates small demands into one and increases the contract volume, as well as the contract value. As a result, contract value and joint procurement can affect the possibility of a green contract in the same direction and also in similar ways. Larger volume or larger value of a contract signifies more incentives for profit-driven economic operators to win the contract. Compared with a less-volume contract, economic operators are more willing to endeavor their efforts meeting various requirements, including environmental requirements. Some scholars also use term of economics of scale to explain the larger impelling power of a large-volume contract [19].

A large volume or contract value can also reduce the suppliers' risk to invest in environmental technologies or managements, in the case that they do not fulfill their environmental requirements. Saastamoinen et al. [26] states that procurement contracts can reduce market risk because they improve the demand predictability. Aschhoff and Sofka [27] explain that the market risk is reduced for innovative firms, since the public purchase is contracted and a certain quantity of sales is guaranteed. Assuming a green bid with a small value is publicized, and only a handful of companies able to fulfill its environmental requirements, then the bid may be cancelled if not enough offers and competition, and the purchaser may change it to a normal bid. However, if the volume or value is attractive enough to companies, they would be willing to invest in the environmental technology or innovations needed to make a green bid. More candidates appear and more green contracts are signed.

In our interview with Ard den Outer, civil servant of Rotterdam Municipality, he stated:

"(In the Netherlands) We have the national government, then we have about 12 provinces and about 300 of municipalities where the contracts are relatively small... if you look at mobile phone contracts, we are very insignificant in that market. They sell so much, what we do is a very small percentage of what they sell per year. So your influence is very different. But in the contracts for buildings, roads, we can make a difference. We are significant amount of the annual turnover of companies, so you can be attractive by volume".

He regards the dispersive small demands from different governments as a big problem when implementing and activating the functions of GPP, "maybe in Europe but definitely in the Netherlands". In contracts with large values or joint procurement, the contracting authorities possess more power to influence private markets, and they are more willing to apply GPP.

\subsection{Business Sectors}

It is rational that different sectors have varying potentials to influence the environment, and the conditions to conduct GPP in sectors are also diverse. With limited budgets and resources, prioritizing some sectors before others is an efficient strategy for public procurement. In our data and variables, ten important sectors were identified, according to their contract volume and EU's decisions.

First, it was evaluated that government construction, including materials and infrastructure, accounts for $28 \%$ of total emissions for the construction sector and for $12 \%$ of government emissions [6]. Construction is regarded as one of the most important sectors for conducting GPP theoretically. From our analysis, architectural, construction, engineering, and inspection services sectors have a larger possibility (by 2.3\%) of developing green contracts than other sectors in total samples. However, the construction work sector has a lower possibility (by 6.4\%) of green contracts in a sample of services. Compared with a significant share of the contract value and the environmental impact of constructions, 
it is not sufficient to tap the potential of GPP in the construction sector. More effort is needed to design and implement GPP in the construction sector.

In addition, transport, food, and electrical products are three other sectors recognized as essential sectors for promoting GPP. There are two sectors within the transport sector: the transport equipment/auxiliary products to transportation, and transport services (excl. waste transport). We obtained a positive estimated marginal effect $(0.058$ or $5.8 \%)$ for transport equipment, but not for transport services. The food sector was estimated to possess higher green likelihood by $8.4 \%$ than other sectors, but no significant results were found for electrical products. It is implied that GPP in the transport equipment and food sectors has been promoted to some extent, especially in product subsamples, while no evidence supports good implementation in the transport service sector.

The medical equipment, pharmaceuticals and personal care products, and the health and social work service sectors were sectors with large contracting values in European countries in 2018. Their estimated effects on green contracts are both negative and larger than 0.05 (or $5 \%$ ). This may demonstrate that in these sectors, it is substantially difficult to promote GPP. Green criteria are indispensable in GPP to convey environmental requirements to the market. Nevertheless, it seems difficult to embody green criteria into medical products, and health and social services.

\subsection{Framework Agreements and GPA}

Framework agreements have generally "involved a contracting authority (or authorities) advertising an opportunity and then entering into a contract or other arrangement with one or more economic operators for the provision of works, supplies or services over a fixed period" [27] (p. 2). The rationale behind framework agreements is to save costs and time for procurement procedures. Generally speaking, the duration of an agreement is no more than four years, during which the contracting bodies can award one or more operators under the framework with no further tendering process or a mini-competition process [28]. Our finding suggests that when comparing the contracts within framework agreements, those without framework agreements have a higher possibility of being green, by $3.1 \%$. Framework agreements tend to hinder the application of green award criteria in award notices, which is supported by results in three subsamples of products, services, and works. This method of purchasing increases the efficiency of projects by limiting the number of tenderers. However, public authorities may miss also the economic operators who possess green technologies and managements.

From our results, we determine that GPA is positively related with green procurement, and this effect is more obvious in products purchasing. GPA encourages public authorities to address environmental considerations in technical specifications and award criteria. Article X-6 provides technical specifications to" promote the conservation of natural resources or protect the environment" and evaluation criteria includes environmental characteristics from Article X-9. What is more, GPA includes the commitment to build a Work Program to "promote the use of sustainable procurement practices, consistent with the Agreement" [17]. These avocations in GPA come into effect from our analysis.

\section{Conclusions}

Green public procurement is expected to reduce environmental impacts and save resources through public procurement. Beyond the public sectors, the leading role of government in the application of environmental technologies and products enhances green development in broader society. To promote GPP, the influential factors which encourage or hinder its application are important. This research aims to find out what aspects can have effects on the adaptation of green award criteria in the contracts with Probit regression and fixed term analysis, using the contract award notice data in 33 European countries in 2018. The data set includes various business sectors and various procurement procedures.

We find that framework agreements, of the medical equipment sector, health and social services sector, and business services sector are negatively related with whether a contract is green, with 
$1 \%$ significance. On the other hand, contract value, GPA coverage, joint procurement, competitive dialogue, negotiation with a call for competition, restricted procedure, transport equipment, and food sector can positively correlate with green contract, or these factors increase the possibility of a contract being green statistically significantly $(1 \%)$.

The contracts applying open procedure possess a lower possibility of green contracts by $5.6 \%$, comparing with contracts with other procurement procedures. After further exploration, we found competitive dialogue, negotiation with a call for competition, and even restricted procedures are positively correlate with green contract, which are more proper for complex form of procurement, like GPP. The contracts with competitive dialogue have a higher probability, of $19 \%$, to apply green award criteria than other procedures. For the contract value and joint procurement, $1 \%$ growth in contract value will increase the probability of the contract being green by $0.48 \%$, and joint contracts are more likely to be green, with a higher likelihood of $4.3 \%$. This implies that a larger volume or value can promote the uptake of green contracts because of larger incentives, while reducing the risk of economic operators.

The four essential sectors for GPP recognized by EU are construction, transport, food, and electrical products. We conclude that GPP is not implemented widely enough in construction work and services, compared with its share in total public purchasing. We determine that transport equipment contracts have a higher possibility to be green, by $5.8 \%$, but did not obtain significant results for transport service. What is more, the food sector is estimated to possess a higher green likelihood ( $8.4 \%$ higher) than other sectors, while no supportive results are found for the electrical products sector. From our results, transport equipment and food demonstrate a better uptake, while more efforts are needed for construction and electrical products. What is more, comparing with the contracts within framework agreements, those without framework agreements have a higher possibility of being green, by $3.1 \%$. This method hinders green criteria, possibly by leaving out green tenderers outside the framework. Last, consistent with its proposals on the environment, GPA positively relates with a contract applying green award criteria.

For future research, the authors recommend investigating green specifications/criteria covered in the whole process of public procurement activities. This research only looks into the green vocabularies included in the contract awarding stage, selecting the final bid winner, which does not take consideration of environmentally related requirements before and after this stage in the procurement process. The green vocabularies identified by authors in determining whether a contract is green or not are restricted to the current 19 sectors with established GPP criteria by the European Commission and confined to limited research time and resources. This research uses fixed effects regression to increase the reliability of the estimations, while the problem of reverse causality is not checked and solved. The authors focus on discussing the relatively significant (within 1\%) factors, as well as on the cross-checked results by total sample and subsamples. What is more, as a comprehensive analysis, this research misses some deep information behind the data, like the application of different types of green criteria. More studies can be conducted in depth on this topic in the future.

Author Contributions: Conceptualization, C.Y. and T.M.; methodology, C.Y.; software, C.Y.; validation, C.Y.; formal analysis, C.Y.; investigation, C.Y., T.M. and H.Y; resources, C.Y. and H.Y.; data curation, C.Y.; writing-original draft preparation, C.Y.; writing-review and editing, C.Y. and H.Y.; visualization, C.Y.; supervision, T.M.; funding acquisition, C.Y and T.M. All authors have read and agreed to the published version of the manuscript.

Funding: This research was funded by the China Scholarship Council.

Acknowledgments: The authors appreciate Anastasia O'Rourke for helping with language editing and correction. Moreover, we thank Ard den Outer for sharing his opinions in the interview.

Conflicts of Interest: The authors declare no conflicts of interest. 


\section{Appendix A Code for Industry Sectors}

14-Mining, basic metals and related products

15-Food, beverages, tobacco and related products

16-Agricultural machinery

18-Clothing, footwear, luggage articles and accessories

19-Leather and textile fabrics, plastic and rubber materials

22-Printed matter and related products

24-Chemical products

30-Office and computing machinery, equipment and supplies except furniture and software packages

31-Electrical machinery, apparatus, equipment and consumables; lighting

32-Radio, television, communication, telecommunication and related equipment

33-Medical equipments, pharmaceuticals and personal care products

34-Transport equipment and auxiliary products to transportation

35-Security, fire-fighting, police and defence equipment

37-Musical instruments, sport goods, games, toys, handicraft, art materials and accessories

38-Laboratory, optical and precision equipments (excl. glasses)

39-Furniture (incl. office furniture), furnishings, domestic appliances (excl. lighting) and cleaning products

$41-$ Collected and purified water

42-Industrial machinery

43-Machinery for mining, quarrying, construction equipment

44 - Construction structures and materials; auxiliary products to construction (except electric apparatus)

45-Construction work

48-Software package and information systems

50-Repair and maintenance services

51-Installation services (except software)

55-Hotel, restaurant and retail trade services

60-Transport services (excl. Waste transport)

63-Supporting and auxiliary transport services; travel agencies services

64-Postal and telecommunications services

65-Public utilities

66-Financial and insurance services

70-Real estate services

71-Architectural, construction, engineering and inspection services

72-IT services: consulting, software development, Internet and support

73-Research and development services and related consultancy services

75-Administration, defence and social security services

76-Services related to the oil and gas industry

77-Agricultural, forestry, horticultural, aquacultural and apicultural services

79-Business services: law, marketing, consulting, recruitment, printing and security

80 -Education and training services

85- Health and social work services

90-Sewage, refuse, cleaning and environmental services

92-Recreational, cultural and sporting services

98-Other community, social and personal services

\section{References}

1. OECD. Promoting Sustainable Consumption: Good Practice in OECD Countries. 2008. Available online: https://www.oecd.org/greengrowth/40317373.pdf (accessed on 10 November 2019).

2. EU. Buying Green, a Handbook of Green Public Procurement. 2016. Available online: https://ec.europa.eu/ environment/gpp/pdf/Buying-Green-Handbook-3rd-Edition.pdf (accessed on 10 November 2019).

3. Kunzlik, P. Green Public Procurement-European Law, Environmental Standards and 'What To Buy' Decisions. J. Environ. Law 2013, 25, 173-202. [CrossRef] 
4. EU. Green and Sustainable Public Procurement. 2019. Available online: https://ec.europa.eu/environment/ gpp/versus_en.htm (accessed on 15 November 2019).

5. Song, X.N.; Wang, K. Construct Responsible Government on Sustainable Government Procurement in Our Country. Environ. Sustain. Dev. 2011, 4, 30-35. (In Chinese)

6. Chiappinelli, O.; Gruner, F.; Weber, G. Green Public Procurement Climate Provisions in Public Tenders Can Help Reduce German Carbon Emissions; DIW Weekly Report 51+52. 2019. Available online: https://www. diw.de/documents/publikationen/73/diw_01.c.701237.de/dwr-19-51-1.pdf (accessed on 10 November 2019). [CrossRef]

7. Lundberg, S.; Marklund, P.-O.; Strömbäck, E.; Sundström, D. Using public procurement to implement environmental policy: An empirical analysis. Environ. Econ. Policy Stud. 2015, 17, 487-520. [CrossRef]

8. Testa, F.; Iraldo, F.; Frey, M.; Daddi, T. What factors influence the uptake of GPP (green public procurement) practices? New evidence from an Italian survey. Ecol. Econ. 2012, 82, 88-96. [CrossRef]

9. Nasiche, F.; Ngugi, G.K. Determinants of adoption of green procurement in the public sector-A case study of Kenya Pipeline Company. Int. J. Soc. Sci. Entrep. 2014, 1, 1-21.

10. Ahsan, K.; Rahman, S. Green public procurement implementation challenges in Australian public healthcare sector. J. Clean. Prod. 2017, 152, 181-197. [CrossRef]

11. Roman, A.V. Institutionalizing sustainability: A structural equation model of sustainable procurement in US public agencies. J. Clean. Prod. 2017, 143, 1048-1059. [CrossRef]

12. The European Commission. Tenders Electronic Daily (csv subset)-Public Procurement Notices. 2018. Available online: https://data.europa.eu/euodp/en/data/dataset/ted-csv (accessed on 21 November 2019).

13. EU. EU GPP Criteria. 2019. Available online: https://ec.europa.eu/environment/gpp/eu_gpp_criteria_en.htm (accessed on 30 November 2019).

14. EU Open Data Portal. TED (csv) Data Information. 2018. Available online: https://data.europa.eu/euodp/en/ data/dataset/ted-csv/resource/99798664-6cf7-4429-b53c-4ecac59f1b6a (accessed on 3 March 2018).

15. Coded Data Description. 2018. Available online: https://simap.ted.europa.eu/web/simap/coded-data (accessed on 10 June 2019).

16. EU. Directive 2014/24/EU of the European Parliament and of the Council on Public Procurement and Repealing Directive 2004/18/EC. Off. J. Eur. Union 2014, 57, 65-242.

17. Abby Semple, L.B.D. Reform of the EU Procurement Directives and WTO GPA Forward Steps for Sustainability. 2012. Available online: https://papers.ssrn.com/sol3/papers.cfm?abstract_id=2089357 (accessed on 1 October 2019).

18. Parikka-Alhola, K.N.A.; Ekroos, A. Green Award Criteria in the Most Economically Advantageous Tender in Public Purchasing; Piga, G., Thai, K.V., Eds.; PrAcademics Press: Boca Raton, FL, USA, 2006.

19. SIGMA. Public Procurement: Central Purchasing Bodies Brief 20. 2011. Available online: http://www. sigmaweb.org/publications/Purchasing_Public_Procurement_2011.pdf (accessed on 1 October 2019).

20. European Commisson. Commission Reconmendation of 6 May 2003 concerning the definition of micro, small and medium-sized enterprises. Off. J. Eur. Union 2003, 46, 36-41.

21. Europa. 2019. Available online: https://ted.europa.eu/TED/browse/browseByBS.do (accessed on 13 December 2019).

22. OECD. Exchange Rates. 2018. Available online: https://data.oecd.org/conversion/exchange-rates.htm (accessed on 13 November 2019).

23. Centre for European Policy Studies (CEPS), College of Europe (Core Team). The Uptake of Green Public Procurement in the EU27 Submitted to the European Commission, DG Environment. 2012. Available online: https://ec.europa.eu/environment/gpp/pdf/CEPS-CoE-GPP\%20MAIN\%20REPORT.pdf (accessed on 10 January 2020).

24. Haugbølle, K.; Pihl, D.; Gottlieb, S.C. Competitive Dialogue: Driving Innovation through Procurement? Procedia Econ. Financ. 2015, 21, 555-562. [CrossRef]

25. Burnett, M. Using Competitive Dialogue in EU Public Procurement-Early Trends and Future Developments. EIPASCOP, 2. 2009. Available online: http://aei.pitt.edu/12381/1/20100114121857_Eipascope_2009_2_Article2. pdf (accessed on 10 October 2019).

26. Saastamoinen, J.; Reijonen, H.; Tammi, T. Should SMEs pursue public procurement to improve innovative performance? Technovation 2018, 69, 2-14. [CrossRef] 
27. Aschhoff, B.; Sofka, W. Innovation on demand-Can public procurement drive market success of innovations? Res. Policy 2009, 38, 1235-1247. [CrossRef]

28. SIGMA. Public Procurement: Framework Agreement Brief 19. 2011, pp. 1-12. Available online: https://www.oecd-ilibrary.org/docserver/5js4vmnmnhf7-en.pdf?expires=1580127850\&id=id\&accname= guest\&checksum=95F5EE654025590CA771ABF41FDCE6D9 (accessed on 1 October 2019).

(C) 2020 by the authors. Licensee MDPI, Basel, Switzerland. This article is an open access article distributed under the terms and conditions of the Creative Commons Attribution (CC BY) license (http://creativecommons.org/licenses/by/4.0/). 